\title{
Soil fertility status in relation to fallow cycles and landuse practices in shifting cultivated areas of Chandel district Manipur, India.
}

\author{
N. Leindah Devi ${ }^{1}$, B.U. Choudhury ${ }^{2}$ \\ ${ }^{1}$ ( Departemnt of Soil Science and Agricultural Chemistry, Tamil Nadu Agricultural University, Tamil Nadu, \\ India) \\ ${ }^{2}$ (Soil Science Division, ICAR-NEH RC, Umiam, Meghalaya, India)
}

\begin{abstract}
Shifting cultivation is the major cultivation in hilly region of North-Eastern India. Shifting cultivation cycles and landuses practices of shifting cultivated area of are considerably related. Fertility status of owing to the shrunk of jhum cycle (2-3 years); resulted deterioration of in soil health and ecological imbalance. So to keep shifting cultivation a sustainable farming system, we examine the relationship between fallow cycles (0-1, 3-5years, 5-7 years, 8-10 years and 12 years) and improved/alternated landuses (intermittent agriculture, agroforestry, abandoned jhum land) in relation to fertility status in shifting cultivated area of Chandel district of Manipur, India. In all landuses short term fallow cycle (3-5 years) deteriorated soil fertility attributes by significant reduction in soil pH, organic carbon and available and total major nutrients. With the increased of fallow cycles (>8 years) its fertility status in all the landuses were significantly restored except intermittent agriculture due to irregular crop fallow rotation. Among the landuses, abandoned jhum land were relatively stable in restoring soil in 5-7 years fallow cycle onwards due to sufficient surface coverage, lack of anthropogenic intervention and internal regulation. Soil restoration starts from 8-10 years onwards in agroforestry system dominated with soil enriching pulse crops and deep rooted nitrogen fixing trees and was remarkable improved from 25 years old pine dominated undisturbed secondary forest ecosystem. Therefore, adoption of improved appropriate landuses in combination with optimum fallow cycles 5-7 years more and proper combination of soil enriching crops and tress have the significant potential in restoring soil fertility status and sustain production in degraded jhum land of northeastern India.
\end{abstract}

Keywords - Fallow cycles, Improved landuses, Shifting cultivation, Soil fertility

\section{INTRODUCTION}

Shifting cultivation (SC) is one of the main forms of crop husbandry in North Eastern Region (NER) of India and it is locally known as jhuming where as the cultivators are known as jhumias. SC in its more traditional and integrated form is ecologically and economically viable system of agriculture as long as the population densities are low and $j h u m /$ fallow cycles are long enough to maintain soil health including fertility [1]. This system often involves clearing of a piece of land followed by wood harvesting or farming, until the soil health gets deteriorated beyond its productive capacity to support crop production. Once the land becomes unproductive, it is left to be reclaimed by regeneration of natural vegetation, or sometimes converted to different long-term cyclical farming practices. Many jhumias use the practice of slash-and-burn as one element of their farming cycle. Others employ land clearing without any burning, and some jhumias are purely migratory and do not use any cyclical method on a given plot. Sometimes no slashing at all is needed where regrowth is purely of grasses, an outcome not uncommon when soils are near exhaustion and need to lie fallow. In NER, though total area under SC has been decreasing, yet, the major concern is the shrinking of fallow periods from the earlier practice of 10-15 years to the present one of 2-3 years. Population pressure, limited land resources owing to difficult and inaccessible hilly terrain features, socio-economic impediments, land tenure systems, rapid decline in soil health and predominance of several other anthropogenic degradation over aggradation processes are responsible for this shrink in fallow periods in NER of India. Short term fallow cycle completely weakens its ability to regenerate under frequent perturbation. As a result, SC system with short term fallow periods (2-3 years) has become one of the most unsustainable farming systems, resulting in a large scale of soil degradation and ecological imbalance. It is believed that adoption of improved/alternate land use practices like agroforestry or lengthening the jhum cycles by abandoning jhuming for longer duration can help substantially in restoring the soil health vis-a vis productive capacity of land. In general, such efforts are underway in NER and more particularly in Manipur, which resulted in substantial decline in current jhum area over a span of few years. However, sufficient information regarding the improvement/restoration of soil health on adoption of alternate system of agriculture is still inadequate. Similarly, information regarding the optimum duration of fallow cycle in regenerating the improvement of soil health is needed for devising any pragmatic approach for restoration 
programmes. Therefore, in the present investigation, an attempt was made to study the soil health under different fallow periods adopted in various improved/ alternate land use practices in one of the shifting cultivated dominant districts (Chandel) of Manipur, India.

\section{MATERIALS AND Methods}

\subsection{Soil and climate of the study area}

The study area is located at the in the south-eastern part of Manipur called Chandel district $\left(24^{\circ} 40^{\prime} \mathrm{N}\right.$ latitude and $93^{\circ} 50^{\prime} \mathrm{E}$ longitude) which experiences hot summer and cold winter. The mean annual temperature exceeds $22^{\circ} \mathrm{C}$ and experiences summer temperature to the range of 35 to $46^{\circ} \mathrm{C}$. The mean annual precipitation varies from 2000 to $2400 \mathrm{~mm}$. The area belongs to warm, humid agro-ecological zone with thermic ecosystem and length of growing period of 300-330 days [2]. The vegetation is predominated by pine including woody and herbaceous species. The soil types of Chandel district are mostly coarser, varying from fine loamy, loamy to sandy in texture and deep in soil depth. Soils of the study area fall under three major soil orders: ultisol, inceptisol and alfisols [2].

\subsection{Site selection}

Jhum cultivation is still the most widely adopted agricultural practices in the district. It is believed that such rampant practices of unsustainable jhuming practices of short duration fallow cycles of 2-3 years in Chandel district is the major contributor to the disturbances in the eco-hydro-geological balance of the area. Total area under shifting cultivation of Chandel district has been undergoing transformation from one system to other with varied lengths of fallow cycle and different land use practices (e.g. natural vegetation, grasses, agroforestry, agriculture etc.). Therefore, for the present investigation, Chandel district was chosen as the study area since all the possible forms of improved/ alternate land use practices on the abandoned shifting cultivated were available. After a preliminary survey of the study area, a central transit was chosen along the shifting cultivated areas with different fallow cycles (e.g. 0-1, 3-4, 5-7, 8-10 and 12 years), presently under different land use practices (e.g. intermittent agriculture, abandoned jhum land and agroforestry) were selected. Secondary mature forest (dominated by Pinus kesiya) of 25 years old in the vicinity of the shifting cultivated area was also selected as reference (control) site. The abandoned jhum lands of different fallow cycles are presently under regenerative grasses mixed with shrubs and trees. Intermittent agriculture represents cultivation of agricultural crops in different jhum cycles in an irregular pattern, particularly in time dimension. In the present study, we have considered the year of first burning of vegetation (first time jhuming) as the benchmark year in determining the age of different fallow cycles. The pictorial views of shifting cultivation in Chandel district of Manipur are shown in the last part of this paper.

\subsection{Sample collection and preparation}

For each landuses soil samples were collected from different reaches of the hillock (upper, middle and lower reaches). The soils were collected from three depths $(0-15 \mathrm{~cm}, 15-30 \mathrm{~cm}$ and $30-45 \mathrm{~cm})$ for each reaches. The soils were taken from 3 spots of each reach and depth, and finally collected soils were composited. The soil samples were air dried, crushed and grounded to pass through a $2 \mathrm{~mm}$ sieve and then analyzed for different chemical properties of the soil. Standard procedures (Table 1) were followed to estimate all the soil fertility parameters.

\subsection{Statistical analysis}

The individual variables such as $\mathrm{pH}, \mathrm{OC}, \mathrm{N}, \mathrm{P}, \mathrm{K}, \mathrm{S}, \mathrm{TN}, \mathrm{TP}$ and TK were analyzed using a two way analysis of variance (ANOVA). The first factor was fallow cycle with five levels $(0-1,3-4,5-7,8-10$ and 12 years post burning period) and second factor was landuse with 3 levels (intermittent agriculture, abandoned jhum and agroforestry practices). Three replications $(\mathrm{r}=3)$ were used to record observations on each variable. Students Newman Keuls Test was used as the post hoc test for multiple comparisons of means. It was also tried to compare the population means of all the chemical variables at the same time. For this, Multivariate Analysis of Variance (MANOVA) was carried out on the data. For MANOVA, the soil depth with 3 levels was also included in the analysis as the third factor. MANOVA hypothesis was tested with the help of Wilks' lamda or Wilk's likehood ratio $(\Lambda)$.

\section{RESUlt AND DiscuSSION}

\subsection{Fallow cycles under different landuse under shifting cultivated area.}

Fallow cycles of different durations i.e. post burning ages and adoption of improved / alternate landuse systems with the dominance of soil enriching leguminous tree species in combination with leguminous crops played a very significant role in ameliorating majority of the soil fertility attributes at varying magnitudes. Irrespective of land uses of different ages, the studied soils were strongly acidic in reaction $(\mathrm{pH}<5.0)$. However, 
the magnitude and nature of change in major soil fertility, parameters varied widely among the three alternate land uses (intermittent agriculture, agro forestry and abandoned jhum) adopted in shifting cultivated area with the increase in age of post burning periods. Impact of land use practices with fallow cycles of different ages on soil chemical attributes was more pronounced at surface layer $(0-15 \mathrm{~cm})$. Therefore, while discussing the variations within each landuse systems, we emphasized only the surface soils $(0-15 \mathrm{~cm})$. However, entire soil depth $(0-30 \mathrm{~cm})$ was considered while representing the significance of fallow cycles) as well as land use practiced on the soil parameters.

\subsubsection{Intermittent agriculture}

In intermittent agricultural system, since regular anthropogenic soil disturbances in the form of cultivation practices were continued, none of the soil chemical parameters reflected any significant improvement with the increase in post burning periods. Rather, inconsistent increase in severity of soil acidity induced deterioration by decreasing the soil $\mathrm{pH}$ by $0.02-0.12$ unit (Fig. 1.1). The extent of deterioration in soil fertility attributes was further aggravated by decreasing the soil organic content to the tune of $16-25 \%$ over freshly burned soils. Availability of macronutrient (N, P, K, S) contents also reduced by over $20 \%$ compared to freshly burned soils, although, partial recovery of nutrient availability was observed in 8-10 years old post burned soils (Table 2). Though the total nutrient (N, P, K) did not show any positive trend with increased in fallow cycle (Fig 1.7, 1.8 and 1.9). However, post burned soils of 8-10 years old reflected relative improvement in nutrient availability. This improvement was mostly due to the combined effect of inorganic fertilizer applied by the jhumias (confirmed from primary source) as well as dominance of leguminous crops cultivation like Glycine max, Vigna mungo, Vigna unguculata etc. In freshly burned soils (0-1 year), ashes were added to the soil which alleviated the soil acidity by increasing $\mathrm{pH}$, thereby increased the availability of nutrients in the soils, especially in the surface [3]. However, this burning effect disappeared gradually from $3^{\text {rd }}$ year onwards as the cultivation progressed along the slopes. Since surface soils lack any vegetative cover and were repeatedly disturbed and exposed to heavy rainfall even in 12 years old cycle, runoff and subsequent loss of top fertile soils might have occurred to a great extent. Cultivation of erosion permitting crops like Zea mays, Colocasia esculenta, Dioscorea bulbifera, Curcuma longa and Zingiber officinale was also practiced along the steep slopes in jhum area. As a result, available nutrient elements and soil aggregation agents like organic carbon might have been lost either through runoff water or leached out from the soil system. Therefore, soils in intermittent agriculture could not recover near to its original health status even after 12 years of post burning period.

\subsubsection{Agroforestry system}

Unlike intermittent agriculture, in agroforestry system, with the increase in post burning periods from 3-4 years to 8-12 years, the soil chemical parameters reflected significant improvement in a consistent manner. Role of leguminous tree species in combination with pulse crops was also quite prominent in rapid restoration of soil chemical attributes, particularly in 8-10 years old cycle. Compared to freshly burned soils ( $0-1$ year old), in 3-4 years old post burn cycle, soil $\mathrm{pH}$ decreased marginally $(<0.05$ unit) (Fig.1.1). Similarly, the deterioration in other important soil fertility parameters like reduction in soil organic carbon content ( $16 \%$ less), less availability of macro nutrients ( $\mathrm{N}$ and $\mathrm{K}$ decreased by $11-16 \%$ while available $\mathrm{P}$ decreased by more than two folds) and total nutrient were decreased by $0.3-0.7$ units (in TN, TP and TK) and continued in 3-4 years old agroforestry systems (Table 2 and Fig 1.7, 1.8 and1.9). In the initial stages (3-4 years) of agroforestry system, surface enrichment of bases, organic carbon, other soil structural cementing agents etc. through litter fall, contribution from root biomass and exudates of tree species were marginal. Since most of the crop canopies were sparse, lack of dense foliage and poor root system, pulverized surface soils favoured faster rate of decomposition of already low organic matter content. As a result, soils having poor aggregation and higher susceptibility to erosion were exposed directly to the heavy rainfall which might have resulted in more runoff and loss of top fertile soil and thus a sharp reduction in bases and nutrients [4],[5];[6]. However, as the age of agroforestry practices increased, particularly from 5-7 years onward, majority of the soil fertility parameters improved considerably, although pace of restoration was remarkably faster in 8-10 years old practices compared to even 12 years old system. By and large, this considerable overall improvement in soil fertility parameters from 5-7 year onwards of agroforestry practices involving various tree-crop combinations including soil enriching nitrogen fixing trees with pulses was mainly attributed to the surface enrichment of organic carbon, bases and several nutrient elements through litter fall, substantial contribution by below ground root biomass, root exudates and organic acids, and incorporation of all weed biomass during intercultural operations [5]. Litter inputs along with dense foliage of 6 or more years old tree system provided necessary surface coverage to the beating action of rain induced splash erosion and thus might have reduced runoff and sediment loss. On the other hand, litter input along with root biomass including exudates and several beneficial microbial catalytic enzymes, polysaccharides etc. encouraged organic matter deposition-decomposition-humification pathways and the subsequent release and accumulation of nutrients including soluble cations $\mathrm{Ca}, \mathrm{Mg}$ and $\mathrm{K}$, soil binding anion $(\mathrm{P})$ and other cementing 
agents. This might have influenced structural regeneration and augmented other soil restoration processes. Among the different ages of agroforestry systems practiced, 8-10 years old agroforestry practices reflected most significant and rapid improvement in soil fertility restoration, which superseded even 12 years old system. Compared to most vulnerable 3-4 years old system, some of the most notable improvements in soil fertility parameters recorded in 8-10 years old practices were increased in soil $\mathrm{pH}$ by 0.54 unit and soil fertility built up (e.g. organic carbon, N, P, K S, TN, TP and TK) increased by more than 50\% [4], [5]. Dominance of various soil enriching nitrogen fixing trees, particularly Parkia, Alnus, Albizia in combination with leguminous crops like Vigna sps., Cajanus cajan, Glycine max etc. in 8-10 years old agroforestry played a pivotal role in restoring the soil health. Since Alnus, Parkia and Albizia are fast growing nitrogen fixing trees with large crown diameter, dense foliage, extensive litter enrichment capability, profuse rooting systems (mostly active fine roots), secretion of substantial root exudates, polysaccharides, enzymes etc. which immensely help in internal catalytic nutrient churning/recycling ability from lower depths and thus surface enrichment of bases, organic matters, nutrients, microbes etc. [7],[8], [3]. Presence of pulse crops further enriched soil fertility and thus microbial activity to obtain optimum physical condition for health restoration and perseveration. In 12 years old system, absence of leguminous species, rather the dominance of water and nutrient exhaustive tree + crop combinations (e.g. Bambusa sps., Quercus serrata, Eucaliptus sps, Musa paradisiaca, Colocasia esculenta, Zea mays, Sachharum officinalis, Pinus kesiya) resulted in slow recovery of soil health.

\subsubsection{Abandoned jhum land}

Similar to agroforestry practices, in abandoned jhum land, with the increase in post burning fallow cycles from 3-4 years to 8-12 years, soil fertility parameters significantly improved. The response of grasses in improving/restoring soil fertility is very fast and unlike agroforestry system, in abandoned jhum land, soil restoration started from 5-7 years onwards. However, alike other land uses, in short term fallow cycle (3-4 years), deterioration of soil health was most severe. Compared to even freshly burn soils, $\mathrm{pH}$ decreased by 0.51 units over a span of 3-4 years (Table 2). Similarly, soil fertility built up like organic carbon and the major nutrient $(\mathrm{N}, \mathrm{P}$, and $\mathrm{K}$ ) were severely declined by $17.02 \%$ and $22-50 \%$, respectively (Fig 1.3, 1.4 and 1.5). However, all the soil fertility parameters demonstrated improvement from 5-7 years onward and the progress continued till 12 years, though 8-10 years of fallow period exhibited greater restoration capability. In 8-10 years fallow period, soil organic carbon content increased by two folds, availability of N,P,K and S content and total nutrient were increased by $8-48 \%$ compared to 3-4 years post burning period (Table 3). This was due to the absence of anthropogenic activity (repeated soil disturbances during cultivation processes) as well as the presence of species like Gynura cusimbua, Eupatorium odoratum, Thysanolaena maxima, Melothria purpusilla, Cymbopogon flexuosus, Hyparrhenia rufa sps, Strychnos nux-blanda, Melastoma malabatericum, Lentinellus cochleatus, Blumea densiflora etc. which provided optimum surface coverage, deposited substantial amounts of organic matter, enriched soil surfaces by recycling of bases and other nutrient elements from sub surfaces through extensive fibrous and deep root systems. Some of them were perennial and over the time (5-7 years onward), developed a deep root system, which penetrated through the compact layer of shallow soil in degraded jhum land. These root mass decay after death and leave root channels, which might have imparted many positive attributes to soil structure and health. It includes structural regeneration and aggregate formations, increase the soil organic carbon content, reduction of the topsoil loss due to erosion, and increase the pore volume and thus facilitation of proper aeration in the root zone. Surface entry of water might have enhanced (evident from higher water retention and availability) and thus reduced the runoff and soil loss to a great extent (low erodibility indices). In hilly region with steep slopes, grasses with profuse rooting behaviour, can act as potential vegetative barrier to minimise runoff and erosion loss. Therefore, the biggest benefits of these grasses in degraded jhum land was the improvement in soil health and quality, to act as an effective agent of soil and water conservation under unfavourable environmental conditions including drought or excess moisture and to improve soil conditions before less robust annual crops can be grown [9],[10].

\subsection{Impact of fallow cycles on soil health parameters}

Irrespective of land uses practiced in shifting cultivated area, freshly burned (0-1 year old) soils (average of $0-45 \mathrm{~cm}$ depth) reflected relatively higher soil $\mathrm{pH}$ ( 0.05 unit), compared to 3-4 years old post burning period (Table 3). Soil pH declined in short term cycles (3-4 years), similarly [11] in separate studies reported that with the increase in fallow periods from the fourth year onwards, carbon and soil $\mathrm{pH}$ started to increase due to deposition of above ground biomass through litter fall and in situ-deposition of grasses which resulted in subsequent enrichment with the bases.

Soil fertility built up was also considerably affected by short duration fallow cycles (3-4 years). The organic carbon and availability of other major nutrient (N, P and K) contents were decreased by $46-73 \%$ in just over a span of 3-4 years from fresh burning (Table 3). However, with the increase in post burning fallow periods from 3-4 years onward, soils exhibited consistent increase in fertility built up, more particularly in 8-10 years 
old by $27 \%$ increase in organic carbon and $30-70 \%$ increase in macronutrient $(\mathrm{N}, \mathrm{P}, \mathrm{K}, \mathrm{S}, \mathrm{TN}, \mathrm{TP}$ and TK) contents over 3-4 years cycle (Fig 1.3,1.4,1.5,1.6,1.7,1.8 and 1.9). In 12 years old fallow cycle, the fertility built up was relatively slow compared to 8-10 years old period. Higher organic matter accumulation through litter falls, root biomass, insitu residues from grasses, presence of nitrogen fixing leguminous trees in combination with pulse crops in $8-10$ years old probably played the major role in rapid restoration of soil fertility [12], [13], [14]. Role of organic matter in increasing the fertility was further evident from the strong significant positive correlation of $\mathrm{N}$ and $\mathrm{S}$ content with organic carbon in all land uses $(\mathrm{r}=0.60$ and $\mathrm{r}=0.82, \mathrm{p}<0.05),[15]$ also reported a consistent increase in av. N stocks with the lengthening of fallow periods. Increase in available P in 8 or more years under Alnus, Parkia and Albizia might be attributed to solubilisation of native P (unavailable forms) owing to root exudates and addition of organic matter through fine roots.

\subsection{Impact of improved/alternate land use practices on soil fertility in shifting cultivated area}

Results from the study revealed that irrespective of fallow/post burn periods, adoption of agroforestry and abandoning jhum for longer duration ( 8 or more years) in degraded jhum land can significantly improve majority of the soil fertility attributes compared to intermittent agriculture. The extent of improvement in some of the soil health attributes was even better than the undisturbed Pinus kesiya dominant secondary mature forest of 25 years old. Short duration fallow cycles (3-7 years old) in all the land uses aggravated the deterioration of soil fertility compared to long durations ( 8 or more years). Effect of fresh burning (0-1 year cycle) of biomass, particularly on enhancing $\mathrm{pH}$ and availability on nutrient elements was quite pronounced, which gradually disappeared in the post burning periods of 3-7 years cycle. Again, in all the land uses practiced in shifting cultivated area, it was surface soil $(0-15 \mathrm{~cm})$ which was significantly affected by the land use practiced in different fallow /post burn periods.

In comparison, the traditional agroforestry system (AFS) has shown a remarkable ability with regards to restoration of overall soil fertility in degraded jhum land. However, due emphasis should be given while selecting proper combination of soil enriching nitrogen fixing, fast growing, profuse root growth tree species along with remunerative pulses/legumes having good surface covering capacity to sustain land productivity on long run. Therefore, agroforestry practices enumerated above could be successfully advocated for areas experiencing similar soil and climatic conditions and as a whole will be a suitable alternative to shifting cultivation in north eastern hill region of India.

\section{FIGURES AND TABLES}

Table 1. Estimation of different soil fertility attributes

\begin{tabular}{|l|l|l|}
\hline Parameter & Method/Instrument & Reference \\
\hline Soil $\mathrm{pH}(1: 2)$ & $1: 2$ soil- water suspension & Jackson (1973) \\
\hline Soil organic carbon & Wet digestion method & Walkley and Black (1934) \\
\hline Available Nitrogen & Alkaline Potassium Permanganate Method & Subbiah and Asija (1956) \\
\hline Available Phosphorus & Bray's II Method & Bray and Kulez (1945) \\
\hline Available Potassium & Neutral N NH${ }_{4}$ OAC method & Jackson (1973) \\
\hline Available Sulphur & Turbidimetric Procedure & Baruah and Borthakur (1997) \\
\hline Total Nitrogen & Modified Kjeldahl Method & Jackson (1973) \\
\hline Total Phosphorus & Ammonium phosphomolybdate & Jackson (1973) \\
\hline Total Potassium & Flame photometer & Jackson (1973) \\
\hline
\end{tabular}

Table 2. Effect of land uses practices on soil fertility parameters in shifting cultivated area.

\begin{tabular}{|l|l|l|l|l|l|l|l|l|l|}
\hline Land uses & $\mathrm{pH}$ & $\begin{array}{l}\text { O.C. } \\
(\%)\end{array}$ & $\begin{array}{l}\text { Av. N } \\
(\mathrm{kg} / \mathrm{ha})\end{array}$ & $\begin{array}{l}\text { Av. P } \\
(\mathrm{kg} / \mathrm{ha})\end{array}$ & $\begin{array}{l}\text { Av. K } \\
(\mathrm{kg} / \mathrm{ha})\end{array}$ & $\begin{array}{l}\text { Av. S } \\
(\mathrm{kg} / \mathrm{ha})\end{array}$ & $\begin{array}{l}\text { Total } \\
\mathrm{N}(\%)\end{array}$ & $\begin{array}{l}\text { Total } \\
\mathrm{P}(\%)\end{array}$ & $\begin{array}{l}\text { Total } \\
\mathrm{K}(\%)\end{array}$ \\
\hline $\begin{array}{l}\text { Intermittent } \\
\text { agriculture }\end{array}$ & 4.40 & $1.55^{\mathrm{a}}$ & $161.78^{\mathrm{a}}$ & $8.61^{\mathrm{a}}$ & $171.26^{\mathrm{a}}$ & $13.94^{\mathrm{a}}$ & $0.185^{\mathrm{a}}$ & $0.084^{\mathrm{a}}$ & $1.093^{\mathrm{a}}$ \\
\hline Agroforestry & 4.50 & $1.56^{\mathrm{a}}$ & $203.99^{\mathrm{b}}$ & $9.61^{\mathrm{b}}$ & $176.75^{\mathrm{b}}$ & $18.26^{\mathrm{b}}$ & $0.190^{\mathrm{b}}$ & $0.093^{\mathrm{b}}$ & $1.209^{\mathrm{b}}$ \\
\hline $\begin{array}{l}\text { Abandoned } \\
\text { jhum land }\end{array}$ & 4.51 & $2.27^{\mathrm{b}}$ & $218.24^{\mathrm{c}}$ & $16.71^{\mathrm{c}}$ & $230.81^{\mathrm{c}}$ & $24.48^{\mathrm{c}}$ & $0.207^{\mathrm{c}}$ & $0.106^{\mathrm{c}}$ & $1.720^{\mathrm{c}}$ \\
\hline
\end{tabular}

$n=45 ;$ Statistical test $=$ Student-Newman-Keuls test; Means in the column followed by common letter are not statistically different at $5 \%$ level of significance.

Table 3. Effect of fallow cycles on soil fertility parameters under different land uses practices in shifting cultivated area.

\begin{tabular}{|l|l|l|l|l|l|l|l|l|l|}
\hline Fallow cycles & $\mathrm{pH}$ & $\begin{array}{l}\text { O.C. } \\
(\%)\end{array}$ & $\begin{array}{l}\text { Av. N (kg/ } \\
\text { ha) }\end{array}$ & $\begin{array}{l}\text { Av. P (kg/ } \\
\text { ha) }\end{array}$ & $\begin{array}{l}\text { Av. K (kg/ } \\
\text { ha) }\end{array}$ & $\begin{array}{l}\text { Av. S (kg/ } \\
\text { ha) }\end{array}$ & $\begin{array}{l}\text { Total N } \\
(\%)\end{array}$ & $\begin{array}{l}\text { Total P } \\
(\%)\end{array}$ & $\begin{array}{l}\text { Total K } \\
(\%)\end{array}$ \\
\hline 0-1year & 4.42 & $1.82^{\mathrm{b}}$ & $227.01^{\mathrm{e}}$ & $12.92^{\mathrm{d}}$ & $232.86^{\mathrm{e}}$ & $20.88^{\mathrm{d}}$ & $0.214^{\mathrm{d}}$ & $0.103^{\mathrm{d}}$ & $1.289^{\mathrm{b}}$ \\
\hline 3-4 years & 4.37 & $1.55^{\mathrm{a}}$ & $155.45^{\mathrm{a}}$ & $8.18^{\mathrm{a}}$ & $156.76^{\mathrm{a}}$ & $16.19^{\mathrm{a}}$ & $0.147^{\mathrm{a}}$ & $0.078^{\mathrm{a}}$ & $1.147^{\mathrm{a}}$ \\
\hline 5-7 years & 4.46 & $1.80^{\mathrm{b}}$ & $180.45^{\mathrm{b}}$ & $11.51^{\mathrm{c}}$ & $182.30^{\mathrm{b}}$ & $17.92^{\mathrm{b}}$ & $0.195^{\mathrm{c}}$ & $0.096^{\mathrm{c}}$ & $1.306^{\mathrm{c}}$ \\
\hline 8-10 years & 4.54 & $1.97^{\mathrm{c}}$ & $218.57^{\mathrm{d}}$ & $14.53^{\mathrm{e}}$ & $203.90^{\mathrm{d}}$ & $21.26^{\mathrm{e}}$ & $0.228^{\mathrm{e}}$ & $0.114^{\mathrm{e}}$ & $1.396^{\mathrm{d}}$ \\
\hline 12 years & 4.55 & $1.83^{\mathrm{b}}$ & $191.91^{\mathrm{c}}$ & $11.09^{\mathrm{b}}$ & $188.89^{\mathrm{c}}$ & $18.22^{\mathrm{c}}$ & $0.186^{\mathrm{b}}$ & $0.082^{\mathrm{b}}$ & $1.566^{\mathrm{e}}$ \\
\hline
\end{tabular}


$n=45$; Statistical test $=$ Student-Newman-Keuls test; Means in the column followed by common letter are not statistically different at 5\% level of significance.

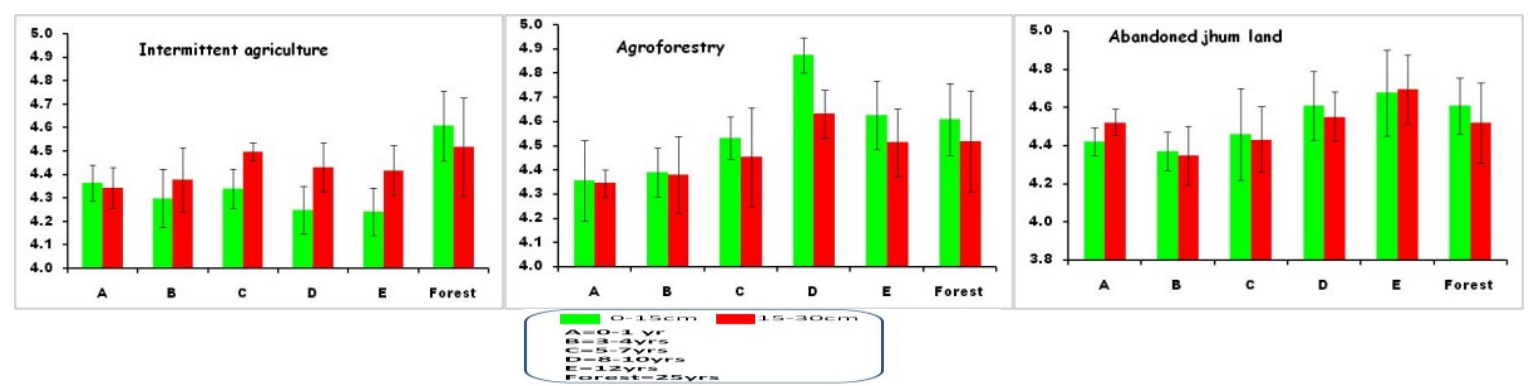

Fig.1.1 Effect of fallow cycles on soil $\mathrm{pH}$ under different land uses in shifting cultivated areas.
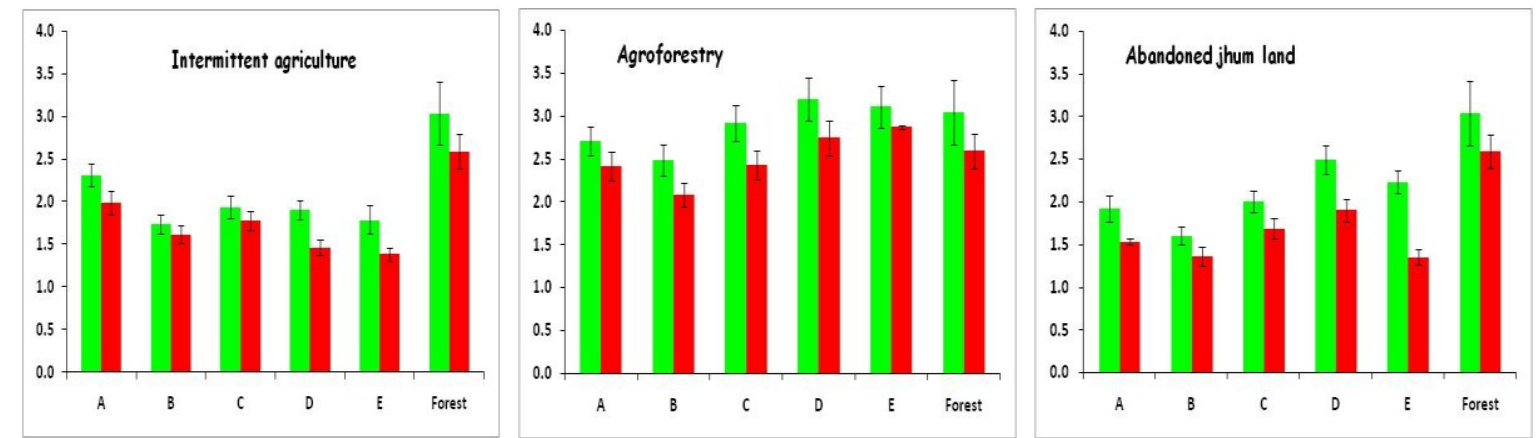

Fig.1.2 Effect of fallow cycles on soil OC (\%) under different land uses in shifting cultivated areas.

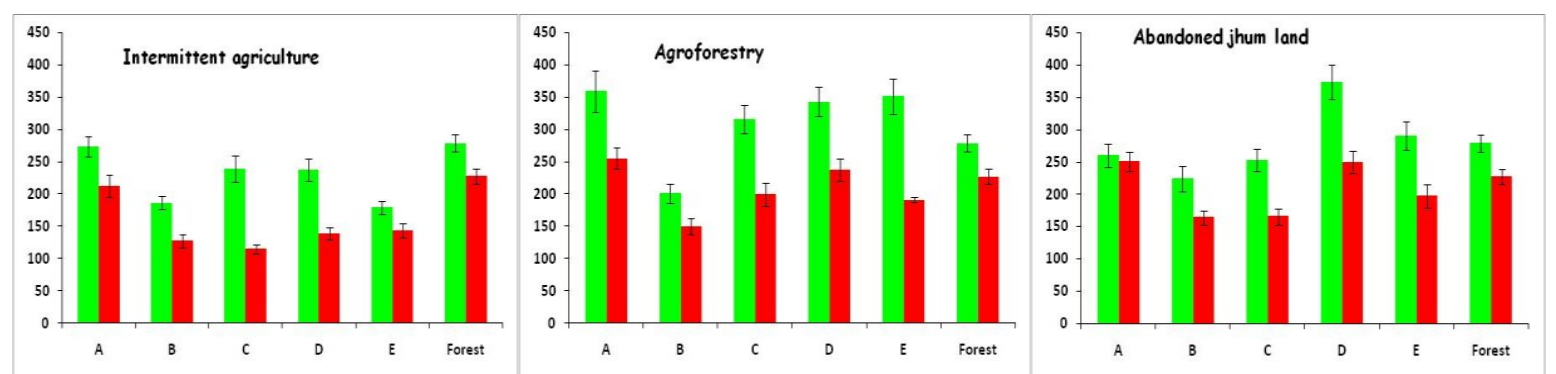

Fig.1.3 Effect of fallow cycles on soil Av.N(Kg/ha) under different land uses in shifting cultivated areas.

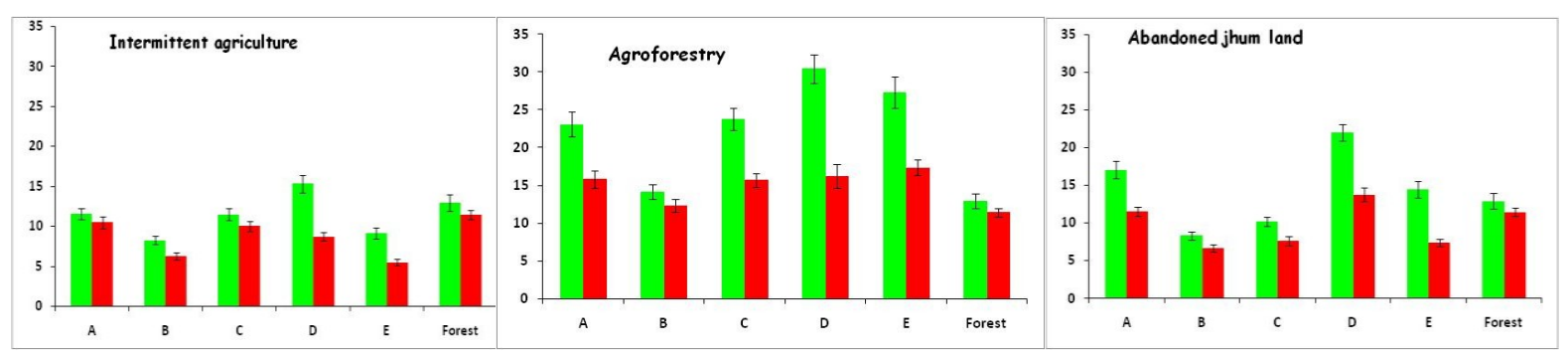

Fig.1.4 Effect of fallow cycles on soil Av.P (Kg/ha) under different land uses in shifting cultivated areas.

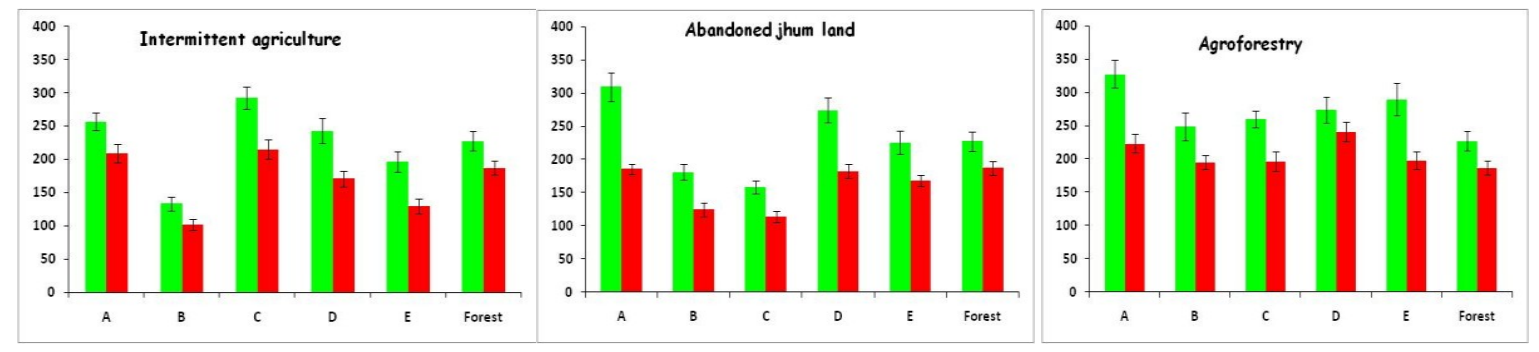

Fig.1.5 Effect of fallow cycles on soil Av.K (Kg/ha) under different land uses in shifting cultivated areas. 


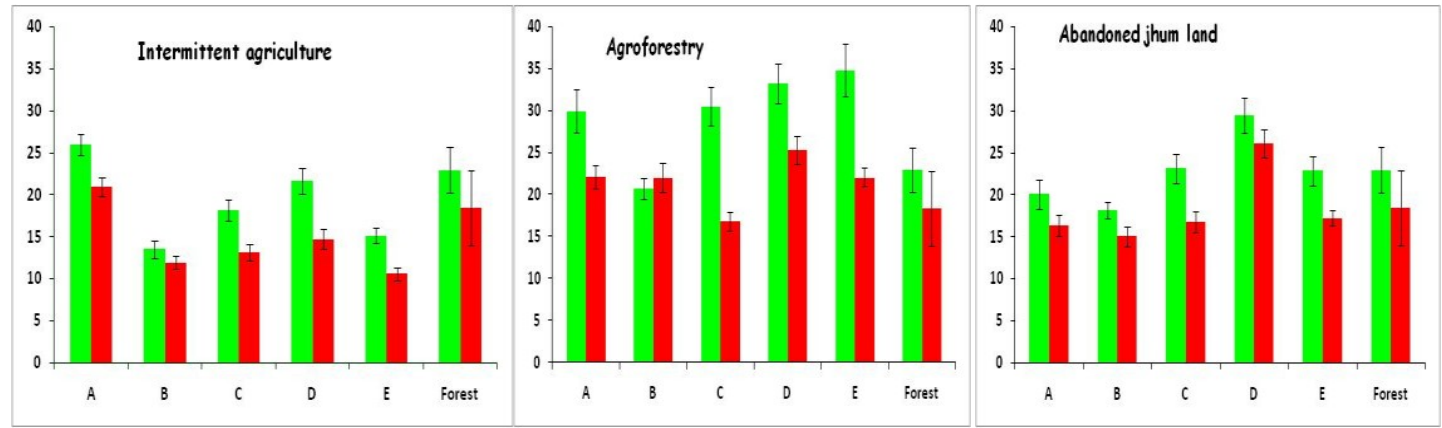

Fig.1.6 Effect of fallow cycles on soil Av.S (Kg/ha) under different land uses in shifting cultivated areas.

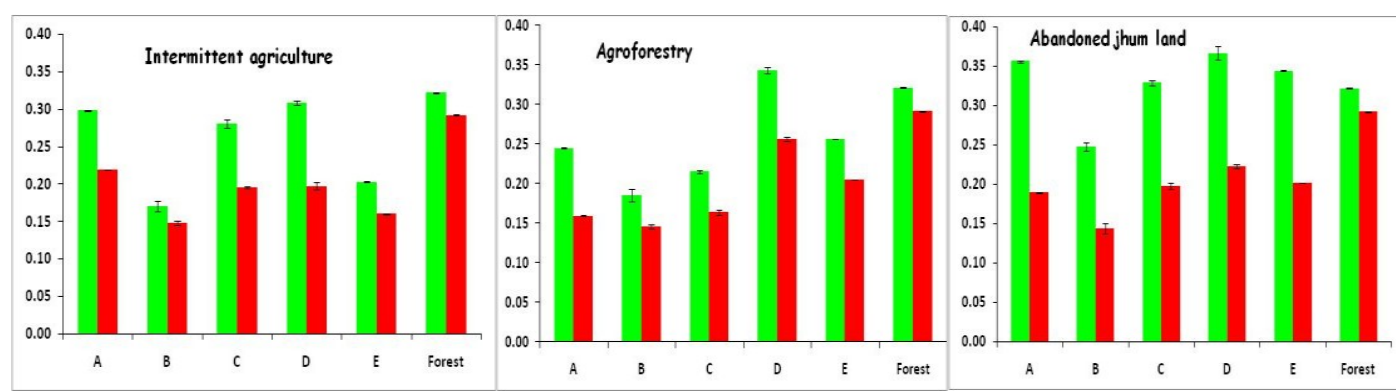

Fig.1.7 Effect of fallow cycles on soil total N (\%) under different land uses in shifting cultivated areas.

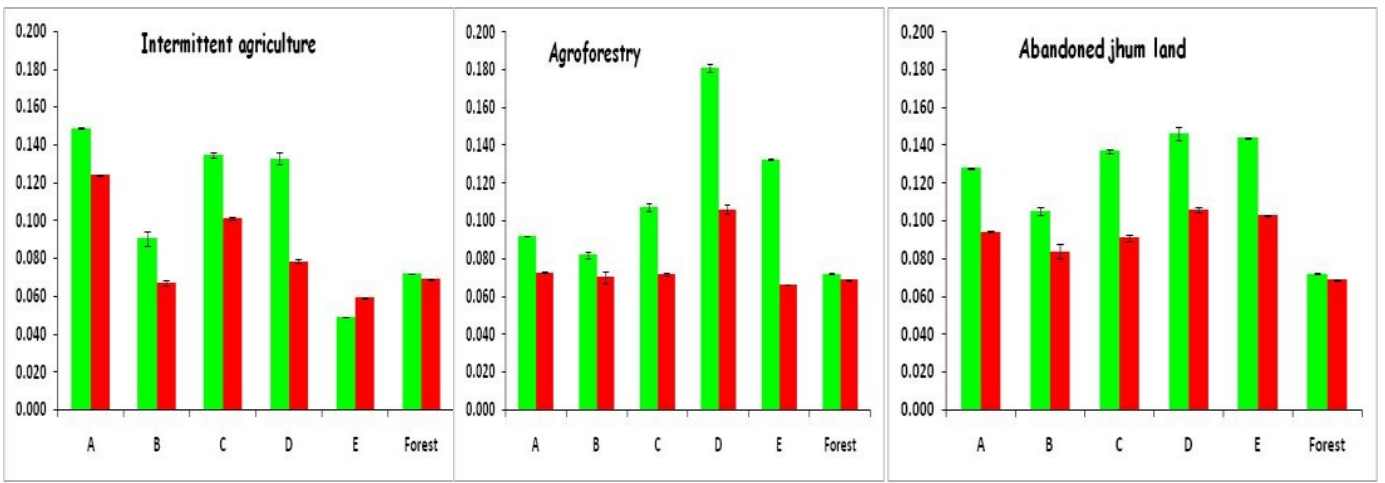

Fig.1.8 Effect of fallow cycles on soil total P (\%) under different land uses in shifting cultivated areas.

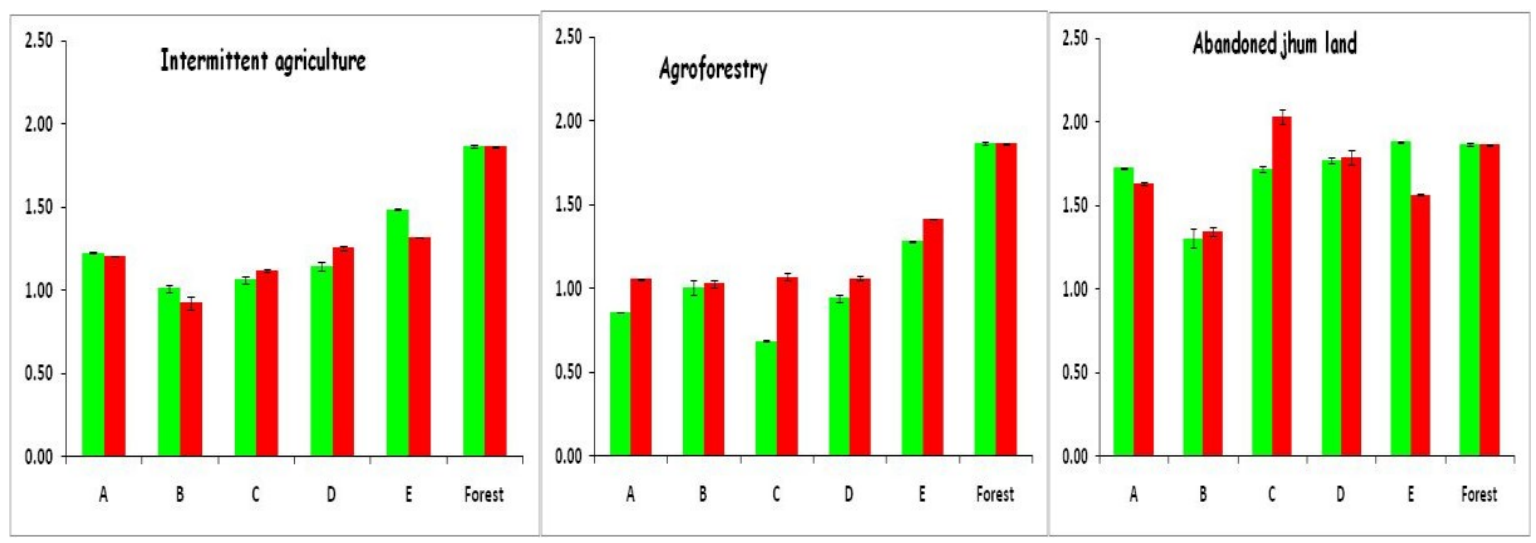

Fig.1.9 Effect of fallow cycles on soil total K (\%) under different land uses in shifting cultivated areas. 

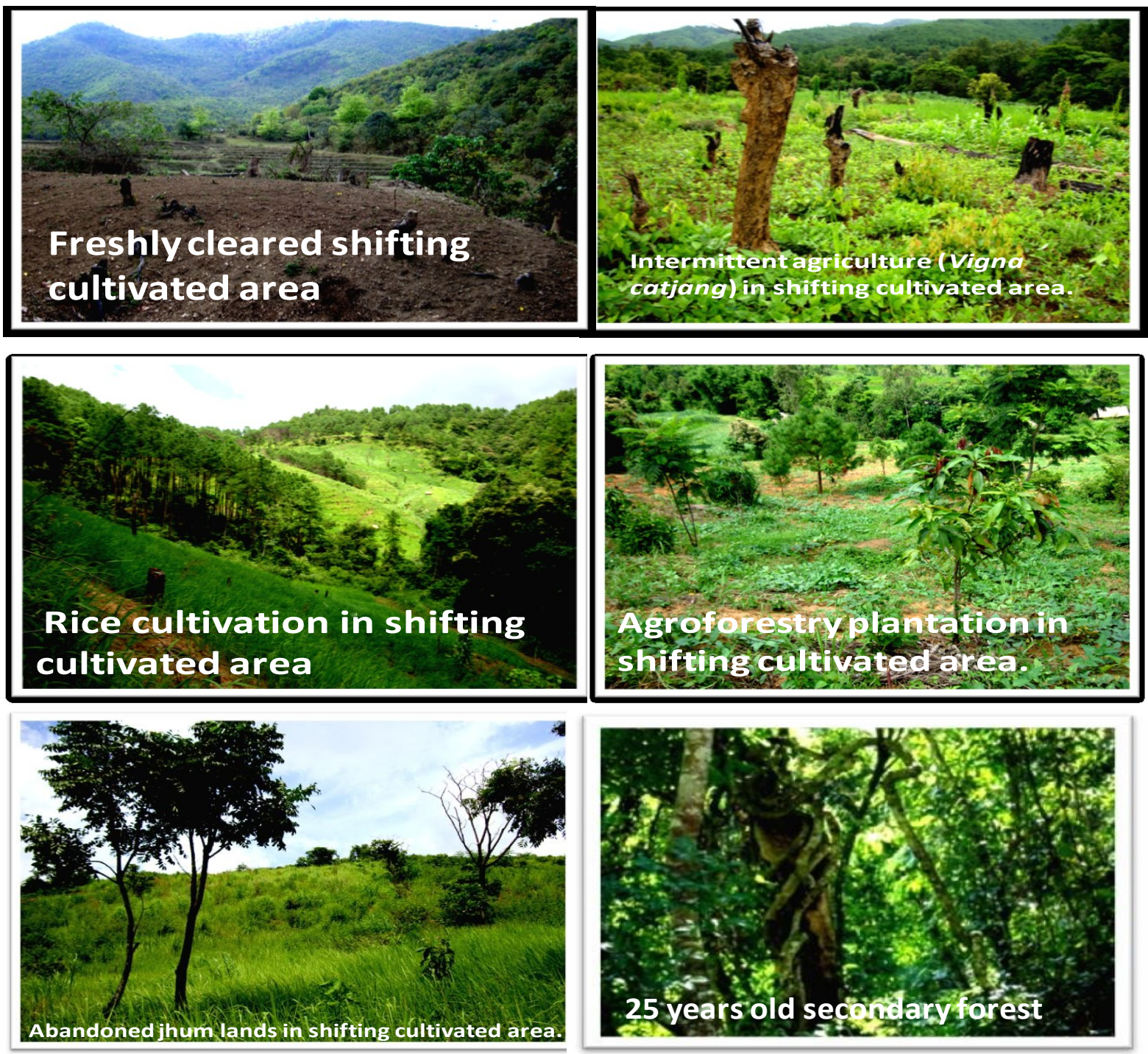

Fig.2 Pictorial views of shifting cultivation in Chandel district of Manipur, India.

\section{CONCLUSION}

Among the improved/alternate land uses practiced in jhum land, agroforestry system of 8-10 years old, dominated by soil enriching leguminous trees and pulse crops combination or abandoning jhum land for at least 5-7 years or more to allow the soil regain its natural restoration ability through perennial grasses are some of the most potential measures in reclaiming degraded jhum lands. Irregular crop-fallow rotation in intermittent agriculture resulted in repeated soil disturbances and thus reduced the soil resilience and so restoration capacity as well. In aggradation-degradation cycle of ecosystem health, shrunk of jhum cycle to 3-4 years as well as intermittent agricultural production system are certainly acting as a precursor in escalating the pace of degradation over aggradation processes.

Therefore, it can be concluded that for reclamation and restoration of soil health in degraded jhum lands, particularly in Northeastern Hilly Regions of India, adoption of agroforestry system can be a viable option, provided selection of proper combination of crops and trees are done which should be soil enriching and complimentary to each other.

\section{Acknowledgements}

The authors are especially gratefully to Dr. S.V. Ngachan, Director, ICAR Research Complex for NEH Region and Dr. V.T. Raju, Ex-Dean College of Post Graduate Studies and School in-charge of Natural Resource Management, CPGS, CAU, Umiam for their valuable suggestions during the course of investigation. One of the authors N. Leindah Devi is very highly pleased to acknowledge University Grants Commission (UGC) for providing financial assistance through scholarship received during the course of study. 


\section{REFERENCES}

[1] Anon. Agro-climatic planning for agricultural development in Meghalaya. Working group, Zonal Planning Team, Eastern Himalayan Region, AAU, Jorhat, Assam. (1992).

[2] Sen, T.K., Baruah, U., Sarkar, D., Maji, A.K. and Patil, V.P.. Soil Series of Manipur. Publ. 134.NBSS and LUP, Nagpur. (2006). pp.53

[3] Tanaka, S., Kendawang, J.J., Yoshida, N., Shibata, K., Jee, A., Tanaka, K., Ninomiya, I. and Sakurai, K.. Effects of Shifting Cultivation on Soil Ecosystems in Sarawak, Malaysia II. Changes in soil chemical properties and runoff water at Balai Ringin and Sabal experimental sites. Soil Science and Plant Nutrition. 50 (5). 2004, 689-699.

[4] Singh, B.P., Madhumita Das and Prasad, R.N. Effect of different landuse systems on nutrient availability in hill terrains of Meghalaya (India). Proc. of the Inter. Symp. on Nutrient Management for sustained productivity. Vol.II. 1992, 60-62.

[5] Dhyani, S.K. and Chauhan, D.S.. Agroforestry practices of North-Eastern hill region of India. In: Agroforestry traditions and innovations (ed.P.Narain et al.,) CSWCR\&TI, Dehradun. 1994,19-23.

[6] Arunachalam, A.. Dynamics of soil nutrients and microbial biomass during first year cropping in an 8-year jhum cycle. Nutrient Cycling in Agroecosystems. 64, 2002, 283-291.

[7] Kass, D.L., Arya, S.J.S., Sanchez, J.O., Pinto, L.S. and Ferreira, P. Ten years experience with alley farming in Central America. Plant and Soil. 63,1992, 165-179.

[8] Singh, G. and Singh, N.T., Dagar, J.C., Singh, H. and Sharma, V.P. An evaluation of agriculture, forestry and agroforestry practices in a moderately alkali soil in northwestern India. Agroforestry Systems. 37, 1997, 279-295.

[9] Entz, M.H., Baron, V.S., Carr, P.M., Meyer, D.W., Smith, S.R. and McCaughey, W.P.. Potential of forages to diversify cropping systems in the northern Great Plains. Agronomy Journal. 94, 2002,240-250.

[10] Katsvairo, T.W., Wright, D.L., Marois, J.J., Hartzog, D.L., Rich, J.R., and Wiatrak, P.J.. Sod-Livestock Integration into the PeanutCotton Rotation: A Systems Farming Approach. Agronomy Journal. 98, 2006,1156-1171.

[11] Venkatesh, M.S., Mishra, A.K., Satapathy, K.K. and Patiram.. Effect of burning on soil properties under Bun cultivation in Meghalaya. Journal of Hill Research. 14(1), 2001, 21-25.

[12] Funakawa, S., Tanaka, S., Kaewkhongkha, T., Hattori, T. and Yonebayashi,K.. Soil ecological study on dynamics of K, Mg and Ca and soil acidity in shifting cultivation in Northern Thailand. Soil Science and Plant Nutrition. 43 (3), 1997, 695-70

[13] Kang, B.T., Wilson, G.F., Lawson, T.L.. Alley Cropping: A Stable Alternative to Shifting Cultivation. International Institute of Tropical Agriculture, Ibadan, Syria. (1984)

[14] Christanty, L.. Shifting Cultivation and Tropical Soils: Patterns, Problems, and Possible Improvements. Traditional agriculture in south east Asia: A human ecology perspective, West view press (Boulder, Colarado). (1986), 226-240

[15] Bruun, T.B., Mertz, O. and Elberling, B. Linking yields of upland rice in shifting cultivation to fallow length and soil properties. Agriculture, Ecosystems and Environment. 113, 2006,139-149. 